\title{
Assessment of Physiological Traits for Adaptation to Flowering Stage Water Deficit in Rainfed Lowland Rice (Oryza sativa L.)
}

\author{
Prabhasmita Shatpathy ${ }^{1}$, Arti $^{2}$, Surendra Pratap Singh ${ }^{3}$, \\ Sanat Kumar Dwibedi ${ }^{4}$ and Abhiram Dash ${ }^{5}$ \\ ${ }^{1}$ Department of Plant Physiology, Odisha University of Agriculture and Technology, \\ Bhubaneswar, Odisha, India \\ ${ }^{2}$ Department of Crop Physiology, Narendra Deva University of Agriculture and Technology, \\ Kumarganj, Faizabad, India \\ ${ }^{3}$ Department of Crop Physiology, Indian Institute of Sugarcane Research, Dilkusha \\ Raibareilley Road, Lucknow, Uttar Pradesh, India \\ ${ }^{4}$ Department of Agronomy, Odisha University of Agriculture and Technology, Bhubaneswar, \\ Odisha, India, \\ ${ }^{5}$ Department of Agricultural Statistics, Odisha University of Agriculture and Technology, \\ Bhubaneswar, Odisha, India \\ *Corresponding author
}

\section{A B S T R A C T}

\section{Keywords}

Rice, Flowering stage, Moisture deficit, Physiological and biochemical traits

\section{Article Info}

Accepted: 04 September 2019 Available Online: 10 October 2019
Responses of 4 cultivars of rice viz. NDR-8002, TCA-48, IR-42 and BPT 5204 to varying levels of moisture deficit stress at flowering stage were assessed in the plastic tubs for their relative tolerance to drought. Moisture deficit adversely affected the apparent translocation rate, relative leaf water content, total chlorophyll content and total soluble carbohydrate content, while proline accumulation enhanced irrespective of varieties. Grain yield decreased conspicuously in all the varieties in response to water stress. Amongst the rice varieties, NDR-8002 and TCA-48 were noted to be relatively more drought tolerant than other 2 cultivars on the basis of their yield performance. The flowering stage in rice was found to be very critical to moisture deficit stress.

\section{Introduction}

Drought and prolonged dry spells are worldwide problems that significantly influence the grain quality and quantity. The situation has been worsening with the ever burgeoning global population and climate change (HongBo et al., 2005). Rice, a semi aquatic field crop is very much susceptible to deficit water stress conditions (Tao et al., 2006; Yang 
et al., 2008). Near about $50 \%$ of the world production of rice is affected more or less by drought (Bouman et al., 2005). In rainfed areas such climatic aberrations are frequent having far off consequences with dwindling productivity. As stable and high yields of rainfed lowland rice are highly essential for food security in many of the subsistence farming system in Asia (Cooper, 1999), growing of rice in Eastern India in around 10 $\mathrm{m}$ ha under vulnerable rainfed lowland farming situation is the greatest challenge before us.

Drought at the flowering stage is highly detrimental to rice plants. It hampers anthesis and seed setting leading to higher spikelet sterility and lower yield in rice (Ram et al., 1988). It also reduces effective leaf area and photosynthesis, thus plants have to depend on pre-anthesis reserves which may impart tolerance against internal water deficits (Austin et al., 1980). Therefore, there is urgent need to develop flowering stage drought tolerant lines for rainfed lowlands. This necessitated the characterization of different physiological or morphological traits associated with flowering stage drought tolerance in rainfed lowland rice.

Though plants have naturally evolved several stress adoptive strategies, most of them relate to survivability under stress. However, from the agricultural point of view, any stress adoptive strategy, drought stress in particular, would be useful only if it is associated with superior crop growth rates under a given stressful environment (Kar et al., 2005). Such adoptive types were traditionally selected based on empirical screening methods that did not always result in the expected increase in productivity under water limited conditions. To improve crop productivity, it is being suggested that a 'trait-based' approach to be adopted (Sheshshayee et al., 2003), which would provide a strong impulse to the efforts in assessing the genetic variability under moisture deficit stress condition. The present endeavour is an attempt to study the physiological and biochemical changes occurring due to drought during flowering stage in rainfed lowland rice and to identify the desirable physiological traits related to drought resistance.

\section{Materials and Methods}

The current study was carried out in plastic tubs at the experimental site of the Department of Crop Physiology, Narendra Deva University of Agriculture and Technology, Kumarganj, Faizabad, Uttar Pradesh, India during Kharif 2011 and 2012 as factorial completely randomized design with four rice varieties (viz. IR-42, NDR 8002, BPT 5204, TCA-48) in 3 replications and 3 drought treatments viz. $100 \%$ (saturated) available soil moisture regime (SMR), 50\% available SMR, $25 \%$ available SMR), which was imposed at flowering stage. The native soil was sandy loam with $\mathrm{pH}$ of 6.8 and available $\mathrm{N}$, Olsen's $\mathrm{P}$ and available $\mathrm{K}$ were of 124,18 and $220 \mathrm{~kg}$ $\mathrm{ha}^{-1}$, respectively. Cold winter months with occasional frost and hot and dry summers have been the climatologic features in that area. Seeds were directly sown in the plastic tubs at equidistance. Thinning was done in each tub after seedling emergence and only 10 healthy plants were maintained. Plants under saturated condition were irrigated normally but $50 \%$ and $25 \%$ ASM regimes were maintained by withholding irrigation in tubs. After 4 days of water withholding in tubs, soil sampling was done periodically. After weighing, samples were oven dried and moisture content in soil was computed. When moisture content in soil reached to $14.5 \%$ and $10.75 \%$ in $50 \%$ and $25 \%$ available SMR treatments respectively, drought treatment was terminated by irrigating the tubs. The observations on different characters were taken as per the following procedures. 


\section{Grain /Economic yield}

Panicles of tagged plants were separated from plant then grains were collected and weighed with the help of electronic balance for finding out the grain yield in $\mathrm{g} \mathrm{plant}^{-1}$.

\section{Apparent translocation rate}

Apparent translocation rate (ATR) was computed by using the following formula (Reyniers et al., 1982).

$$
\text { ATR }=\frac{\text { WSF }- \text { WSM }}{\text { WPM }- \text { WPF }}
$$

Where,

WSF is dry weight of stem at flowering,

WSM is dry weight of stem at maturity,

WPM is dry weight of panicle at maturity and

WPF is dry weight of panicle at flowering.

\section{Relative leaf water content}

The relative leaf water content (RLWC) was calculated by using the following formula (Turner and Beg, 1981).

$$
\text { RLWC }=\frac{\text { Fresh weight }- \text { Dry weight }}{\text { Saturated weight }- \text { Dry weight }} \times 100
$$

\section{Total chlorophyll}

Total chlorophyll (Chl) content in leaf sample was estimated according to method of Arnon (1949) and expressed as $\mathrm{mg} \mathrm{g}^{-1}$ fresh weight of leaves. In this method, Chl was extracted in $80 \%$ acetone. $200 \mathrm{mg}$ leaves in $5 \mathrm{~mL}$ of $80 \%$ aqueous acetone were centrifuged at 4,000 rpm for 20 minutes, and the absorbance of the supernatant was measured at 645 and $663 \mathrm{~nm}$ on spectronic-20 using $80 \%$ acetone as blank.

The amount of chlorophyll was calculated as,

$\mathrm{Chl} \mathrm{a}=12.7 \times \mathrm{OD}_{663}-2.69 \times \mathrm{OD}_{645}\left(\mathrm{mg} \mathrm{L}^{-1}\right)$ and

$\mathrm{Chl} b=22.9 \times \mathrm{OD}_{645}-4.68 \times \mathrm{OD}_{663}\left(\mathrm{mg} \mathrm{L}^{-1}\right)$.

Where,

OD = Optical density of the chlorophyll extract at a specific wavelength.

\section{Total soluble carbohydrate}

The total soluble carbohydrate in plant extracts was estimated by the method of Yemmand Willis (1954). The fresh plant sample of $100 \mathrm{~g}$ was homogenized in $10 \mathrm{~mL}$ of $80 \%$ ethanol and centrifuged at $4,000 \mathrm{rpm}$ for 20 minutes. The supernatant was collected and the residue was re-extracted twice with 10 $\mathrm{mL}$ of $80 \%$ ethanol and then again centrifuged at 4,000 rpm for 20 minutes.

All the supernatants were combined and the volume was made to $20 \mathrm{~mL}$. A known volume $(0.1$ to $0.2 \mathrm{~mL})$ of ethanol extract was evaporated to dryness in a test tube on water bath and cooled to room temperature. The distilled water of $1 \mathrm{~mL}$ was then added to each tube and mixed thoroughly. To each test tube, $4.0 \mathrm{~mL}$ of anthrone reagent was added and heated on a water bath at $100{ }^{0} \mathrm{C}$ for 10 minutes. Finally, it was cooled under running cold water and the absorbance was measured at $620 \mathrm{~nm}$ against reagent blank. A standard curve was prepared by using graded concentrations of glucose.

\section{Proline content}

The Proline content was estimated spectrophotometrically according to the method of 
Bates et al., 1973. Fresh leaves were homogenized in $3 \mathrm{~mL}$ of $3 \%$ aqueous sulfosalicylic acid and centrifuged at 4,000 rpm for 20 minutes. The residue was reextracted with $5 \mathrm{~mL}$ of $3 \%$ sulfosalicylic acid and volume was made to $10 \mathrm{ml} .2 \mathrm{~mL}$ of this aliquot was transferred into a test tube and 2 $\mathrm{mL}$ each of acid ninhydrin and acetic acid were added. The mixture was heated on a boiling water bath for one hour, after which reaction was terminated by placing the tube in icebox. Thereafter, the mixture was shaken vigorously with $4 \mathrm{~mL}$ toluene and kept for several hours at room temperature.

Chromatophor was thus extracted into toluene phase, which was separated and its absorbance was measured at $520 \mathrm{~nm}$ using toluene as blank. Standard curve prepared with graded concentration of DL-proline.

\section{Statistical analysis}

The statistical analysis of experimental data was done by the method described by Panse and Sukhatme (1978) using factorial completely randomized design (CRD) experiment. The comparison of the treatment means made with the help of least significant differences calculated as here under.

$$
\begin{aligned}
& \mathrm{SEm} \pm \text { due to variety }=\sqrt{\frac{2 \times \mathrm{EMSS}}{\mathrm{D} \times \mathrm{r}}} \\
& \mathrm{SEm} \pm \text { due to drought }=\sqrt{\frac{2 \times \mathrm{EMSS}}{\mathrm{V} \times \mathrm{r}}}
\end{aligned}
$$$$
\mathrm{SEm} \pm \text { due to variety } \mathrm{x} \text { drought }=\sqrt{\frac{2 \mathrm{x} \text { EMSS }}{\mathrm{r}}}
$$

$\mathrm{CD}=\mathrm{SEm} \times \mathrm{t}$ at $5 \%$ for error d.f.

Where,
$\mathrm{V}=$ number of varieties

$\mathrm{r}=$ number of replications

$\mathrm{t}=$ table value at $5 \%$ for error d.f.

$\mathrm{D}=$ Drought levels

EMSS $=$ error means sum of square

d.f. $=$ degrees of freedom

$\mathrm{SEm}=$ standard error of means

\section{Results and Discussion}

\section{Grain yield}

Moisture deficit stress at flowering stage caused a severe reduction in grain yield of all varieties (Table 1). The percent reduction in grain yield at $50 \%$ available SMR over saturated condition ranged from $17 \%$ to $31 \%$ which increased to the tune of $32.2 \%$ to $48.2 \%$ at $25 \%$ available SMR. Under both moisture deficit stresses, the minimum percent reduction in grain yield was observed in rice cv. NDR-8002 followed by TCA-48, while IR-42 had the highest reduction. The mean effect of varieties showed the highest grain yield in NDR-8002 followed by TCA-48, BPT-5204 and IR-42. The mean effect of stress exhibited $23.4 \%$ and $39.7 \%$ reduction in grain yield at $50 \%$ and $25 \%$ available SMR, respectively over saturated condition. The present result also corroborated the earlier findings of Sarvestani et al., (2008) with reduction in total biomass, harvest index, filled grains, unfilled grains and 1000 grain weight under water stress in rice cultivars at flowering stage.

\section{Apparent translocation rate}

The apparent translocation rate (ATR) is the relative decrease or increase in stem dry 
weight compared to panicle dry weight. It is an indirect measurement of translocatory behaviour of stem reserve to panicle growth. The data presented in Table 1 clearly showed significant and progressive increase in ATR with increase in moisture deficit stress level. Significantly, the highest ATR value in all varieties was recorded at $25 \%$ available SMR and the saturated condition trailed behind in this line. At $50 \%$ and $25 \%$ available SMR, the increase in ATR over saturated condition ranged from $18.7 \%$ (IR-42) to $27.8 \%$ (TCA48 ) and $35 \%$ (IR-42) to $50 \%$ (TCA-48), respectively. The mean effect of drought showed $26.7 \%$ and $40 \%$ increase in ATR at $50 \%$ and $25 \%$ available SMR, respectively over saturated condition. The present result also corroborated the findings of Reyniers et al., (1982), Chaturvedi and Ingram (1991) and Arti (2006). Among the rice varieties, NDR8002 and TCA-48 showed higher percent increase in ATR under moisture deficit stresses with respect to saturated condition. It means these varieties have better capacity to translocate reserve food materials from the stem to panicles under drought condition than other varieties.

\section{Relative leaf water content}

The relative leaf water content (RLWC) was severely reduced under moisture deficit stress condition (Table 2). The reduction in RLWCs of all varieties were more at $25 \%$ available SMR as compared to $50 \%$ available SMR. At $50 \%$ available SMR, the maximum reduction in RLWC over saturated condition was recorded in IR-42 (24.3\%), while TCA-48 showed the minimum reduction $(13.1 \%)$. At $25 \%$ available SMR also the maximum and the minimum percent reduction in RLWC over saturated condition were found in IR-42 (31.8\%) and TCA-48 (23.5\%), respectively. The mean effect of varieties showed the highest RLWC in TCA-48 which was at par with NDR-8002 but significantly higher than
BPT-5204 and IR-42. The mean effect of drought showed $17.2 \%$ and $26.7 \%$ reduction in RLWC at $50 \%$ and $25 \%$ available SMR, respectively over saturated condition. Many researchers have reported that reduction in RLWC might be due to hydrolysis of reserve protein and starch or due to non-utilization of these products for growth, as a result concentration of soluble sugars, minerals, betaine, proline and other free amino acids increases in the cell sap, such accumulation might have resulted in the lowering of solute potential and consequently decrease the RLWC. It has also been observed in our experiment that proline and soluble carbohydrates were comparatively high in NDR-8002 and TCA-48 than other varieties of rice under moisture deficit stresses (Table 3 ). This might have resulted in maintaining better RLWC by above varieties than rest of the varieties. Our study also confirms the findings of Chaturvedi et al., (2004) who observed water deficit at flowering stage declining the RLWC in rice significantly and the reduction was more in susceptible genotypes than tolerant ones. During recovery from moisture deficit stress, the reduction in RLWC with respect to saturated condition was also minimized.

\section{Total chlorophyll}

At the end of drought, all the varieties showed decrease in total chlorophyll at both $50 \%$ and $25 \%$ available SMR relative to saturated condition, however extent of decrease was more at $25 \%$ available SMR (Table 2). At both $50 \%$ and $25 \%$ of the available SMR, the highest chlorophyll content was found in NDR-8002 followed by BPT-5204 and TCA48 in descending order; IR-42 had the least. The mean effect of variety indicated the highest chlorophyll in NDR-8002 which was at par with BPT-5204, TCA-48 but significantly higher than IR-42. The mean effect of stress showed $14.7 \%$ and $19.7 \%$ 
decrease in total chlorophyll content at 50\% and $25 \%$ available SMR, respectively over saturated condition. At recovery, all the varieties exhibited decrease in total chlorophyll content at $50 \%$ and $25 \%$ available SMR with respect to saturated condition. Relatively higher chlorophyll content at both $50 \%$ and $25 \%$ available SMR was recorded in NDR-8002 and TCA-48, while BPT-5204 and IR-42 had lower chlorophyll content. The mean effect of drought showed that at $25 \%$ available SMR, chlorophyll content significantly declined below 50\% available SMR and saturated condition. The decrease in chlorophyll content under drought was due to weakening of bonding between chlorophyll and protein complex (Samier and Mafrina, 1982). Sikuku et al., (2010) had also observed decline in total chlorophyll content in rice with increasing water deficit. Similar to the present result, Pandey and Chaturvedi (1993) observed varietal variation in total chlorophyll content of rice under drought; the tolerant varieties had less decrease in total chlorophyll than susceptible ones.

\section{Total soluble carbohydrate}

The total soluble carbohydrate (CHO) in culm decreased with increase in moisture deficit stress level and the extent of decrease was higher at $25 \%$ available SMR (Table 3). At $50 \%$ available SMR, the lowest reduction in total $\mathrm{CHO}$ with respect to saturated condition was found in NDR-8002 $(9.7 \%)$ followed by TCA-48 (12.4\%), BPT-5204 (14\%) and IR-42 (19.9\%). At $25 \%$ available SMR, above varieties followed similar order, however the reduction varied from $15.1 \%$ (NDR-8002) to $29.3 \%$ (IR-42). The mean effect of varieties showed the highest total CHO in NDR-8002 which was significantly higher than other varieties, while the lowest $\mathrm{CHO}$ was observed in IR-42. The mean effect of stress indicated $14 \%$ and $21.6 \%$ reduction in total $\mathrm{CHO}$ at
$50 \%$ and $25 \%$ available SMR, respectively over saturated condition. The rice $\mathrm{cv}$. NDR8002 had the highest total $\mathrm{CHO}$ at both $50 \%$ and $25 \%$ available SMR, while IR-42 showed the lowest values. The mean effect of variety also showed the highest total $\mathrm{CHO}$ in NDR8002 and the lowest in IR-42. As limited water supply inhibits the synthesis of current photosynthates which might be one of the reasons for reduced $\mathrm{CHO}$ level under drought. Secondly, when current photosynthates under drought are limiting, plant survives at the expense of energy obtained from breakdown of stored $\mathrm{CHO}$ pool, this also reduces the CHO status in culm. Similar to the present results, Weng et al., (1986) found wide variability among rice genotypes for $\mathrm{CHO}$ content under drought and observed that the tolerant rice cultivars have higher $\mathrm{CHO}$ content than susceptible ones. According to Chaturvedi and Ingram (1989), high CHO and its remobilization are key components of drought recovery especially for drought tolerance at flowering stage. This indicated that higher $\mathrm{CHO}$ content in NDR-8002 and TCA-48 might be one of the tolerant characters for flowering stage drought. All the varieties showed lower $\mathrm{CHO}$ at both $50 \%$ and $25 \%$ available SMR as compared to saturated condition.

\section{Free proline}

The proline accumulation increased with increase in moisture deficit stress level and the highest accumulation in all varieties was recorded at $25 \%$ available SMR (Table 3 ). At both $50 \%$ and $25 \%$ available SMR, the highest proline content was observed in NDR-8002 which was at par with TCA-48 but significantly higher than BPT-5204 and IR-42. At both $50 \%$ and $25 \%$ available SMR, the highest proline content was found in NDR8002 followed by TCA-48, BPT-5204 and IR42 in reducing manner. 
Table.1 Effect of flowering stage water deficit on grain yield and apparent translocation rate (ATR) of rainfed lowland rice

\begin{tabular}{|c|c|c|c|c|c|c|c|c|}
\hline \multirow[t]{2}{*}{ Varieties } & \multicolumn{4}{|c|}{ Grain yield $\left(\mathrm{g} \mathrm{plant}^{-1}\right)$} & \multicolumn{4}{|c|}{ ATR } \\
\hline & $\begin{array}{c}100 \% \\
\text { available } \\
\text { SMR }\end{array}$ & $\begin{array}{c}\mathbf{5 0 \%} \\
\text { available } \\
\text { SMR }\end{array}$ & $\begin{array}{c}25 \% \\
\text { available } \\
\text { SMR }\end{array}$ & Mean & $\begin{array}{c}100 \% \\
\text { available } \\
\text { SMR }\end{array}$ & $\begin{array}{c}\mathbf{5 0 \%} \\
\text { available } \\
\text { SMR }\end{array}$ & $\begin{array}{c}25 \% \\
\text { available } \\
\text { SMR }\end{array}$ & Mean \\
\hline IR-42 & 16.41 & $\begin{array}{c}11.32 \\
(31.0)\end{array}$ & $\begin{array}{c}8.50 \\
(48.2)\end{array}$ & 12.07 & 0.13 & $\begin{array}{c}0.16 \\
(18.7)\end{array}$ & $\begin{array}{c}0.20 \\
(35.0)\end{array}$ & 0.16 \\
\hline NDR-8002 & 23.01 & $\begin{array}{l}19.09 \\
(17.0)\end{array}$ & $\begin{array}{l}15.60 \\
(32.2)\end{array}$ & 19.23 & 0.17 & $\begin{array}{c}0.23 \\
(26.0)\end{array}$ & $\begin{array}{c}0.29 \\
(41.4)\end{array}$ & 0.23 \\
\hline BPT-5204 & 20.01 & $\begin{array}{l}14.80 \\
(26.0)\end{array}$ & $\begin{array}{l}11.40 \\
(43.0)\end{array}$ & 15.40 & 0.15 & $\begin{array}{c}0.19 \\
(21.1)\end{array}$ & $\begin{array}{c}0.24 \\
(37.5)\end{array}$ & 0.19 \\
\hline TCA-48 & 19.36 & $\begin{array}{l}15.10 \\
(22.0)\end{array}$ & $\begin{array}{l}12.00 \\
(38.8)\end{array}$ & 15.48 & 0.13 & $\begin{array}{c}0.18 \\
(27.8)\end{array}$ & $\begin{array}{c}0.26 \\
(50.0)\end{array}$ & 0.19 \\
\hline Mean & 19.70 & $\begin{array}{l}15.08 \\
(23.4)\end{array}$ & $\begin{array}{l}11.87 \\
(39.7)\end{array}$ & & 0.15 & $\begin{array}{c}0.19 \\
(26.7)\end{array}$ & $\begin{array}{c}0.25 \\
(40.0)\end{array}$ & \\
\hline S.Em $( \pm)$ & $\mathrm{V}=0.38$ & $\mathrm{D}=0.32$ & \multicolumn{2}{|c|}{$\mathrm{V} \times \mathrm{D}=0.65$} & $\mathrm{~V}=\mathbf{0 . 0 1}$ & $\mathbf{D}=\mathbf{0}$ & \multicolumn{2}{|c|}{$V \times D=0.02$} \\
\hline LSD at $5 \%$ & $V=1.09$ & $D=0.94$ & \multicolumn{2}{|c|}{$V \times D=N S$} & $V=0.02$ & $\mathbf{D}=\mathbf{0}$. & \multicolumn{2}{|c|}{$V \times D=0.04$} \\
\hline
\end{tabular}

(SMR: Soil moisture regime; NS: Not significant)

(Values in parenthesis indicate percent decrease due to 50\% and 25\% available SMR calculated over 100\% available SMR)

Table.2 Effect of flowering stage water deficit on relative leaf water content (RWC) and total chlorophyll ( $\mathrm{mg} \mathrm{g}^{-1}$ fresh weight) of rainfed lowland rice (recorded at end of the stress)

\begin{tabular}{|c|c|c|c|c|c|c|c|c|}
\hline \multirow[t]{2}{*}{ Varieties } & \multicolumn{4}{|c|}{ RWC (\%) } & \multicolumn{4}{|c|}{ Total chlorophyll } \\
\hline & $\begin{array}{c}100 \% \\
\text { available } \\
\text { SMR }\end{array}$ & $\begin{array}{c}\mathbf{5 0 \%} \\
\text { available } \\
\text { SMR }\end{array}$ & $\begin{array}{c}25 \% \\
\text { available } \\
\text { SMR }\end{array}$ & Mean & $\begin{array}{c}100 \% \\
\text { available } \\
\text { SMR }\end{array}$ & $\begin{array}{c}\mathbf{5 0 \%} \\
\text { available } \\
\text { SMR }\end{array}$ & $\begin{array}{c}25 \% \\
\text { available } \\
\text { SMR }\end{array}$ & Mean \\
\hline IR-42 & 81.00 & $\begin{array}{l}61.30 \\
(24.3)\end{array}$ & $\begin{array}{l}55.20 \\
(31.8)\end{array}$ & 65.83 & 2.90 & $\begin{array}{c}2.42 \\
(16.5)\end{array}$ & $\begin{array}{c}2.25 \\
(22.4)\end{array}$ & 2.52 \\
\hline NDR-8002 & 82.10 & $\begin{array}{l}70.30 \\
(14.3)\end{array}$ & $\begin{array}{l}62.00 \\
(24.5)\end{array}$ & 71.47 & 3.01 & $\begin{array}{c}2.70 \\
(10.2)\end{array}$ & $\begin{array}{c}2.52 \\
(16.2)\end{array}$ & 2.74 \\
\hline BPT-5204 & 79.30 & $\begin{array}{l}65.60 \\
(17.3)\end{array}$ & $\begin{array}{l}57.70 \\
(27.2)\end{array}$ & 67.53 & 3.11 & $\begin{array}{c}2.54 \\
(18.3)\end{array}$ & $\begin{array}{c}2.50 \\
(19.6)\end{array}$ & 2.72 \\
\hline TCA-48 & 82.30 & $\begin{array}{c}71.50 \\
(13.12)\end{array}$ & $\begin{array}{l}63.00 \\
(23.5)\end{array}$ & 72.27 & 2.93 & $\begin{array}{c}2.52 \\
(14.0)\end{array}$ & $\begin{array}{c}2.36 \\
(19.4)\end{array}$ & 2.60 \\
\hline Mean & 81.18 & $\begin{array}{l}67.18 \\
(17.2)\end{array}$ & $\begin{array}{l}59.48 \\
(26.7)\end{array}$ & & 2.99 & $\begin{array}{c}2.55 \\
(14.7)\end{array}$ & $\begin{array}{c}2.40 \\
(19.7)\end{array}$ & \\
\hline S.Em ( $( \pm)$ & $\mathrm{V}=1.73$ & $\mathrm{D}=1.49$ & \multicolumn{2}{|c|}{$\mathrm{V} \times \mathrm{D}=3.00$} & \multicolumn{2}{|c|}{$\mathrm{V}=0.06 \mathrm{D}=0.05$} & \multicolumn{2}{|c|}{$V \times D=0.10$} \\
\hline LSD at $5 \%$ & $V=4.98$ & $D=4.3$ & $V \times D=$ & NS & $V=($ & $17 D=0.15$ & $V \times D=$ & \\
\hline
\end{tabular}

(SMR: Soil moisture regime; NS: Not significant)

(Values in parenthesis indicate percent decrease due to 50\% and 25\% available SMR calculated over 100\% available SMR) 
Table.3 Effect of flowering stage water deficit on total soluble carbohydrate ( $\mathrm{mg} \mathrm{g}^{-1}$ dry weight) and proline ( $\mu \mathrm{g} \mathrm{g}^{-1}$ fresh weight) in leaves of rainfed lowland rice (recorded at the end of stress).

\begin{tabular}{|c|c|c|c|c|c|c|c|c|}
\hline \multirow[t]{2}{*}{ Varieties } & \multicolumn{4}{|c|}{ Total soluble carbohydrate } & \multicolumn{4}{|c|}{ Proline } \\
\hline & $\begin{array}{c}100 \% \\
\text { availabl } \\
\text { e SMR }\end{array}$ & $\begin{array}{c}50 \% \\
\text { availabl } \\
\text { e SMR }\end{array}$ & $\begin{array}{c}25 \% \\
\text { availabl } \\
\text { e SMR }\end{array}$ & $\begin{array}{c}\text { Mea } \\
\text { n }\end{array}$ & $\begin{array}{c}100 \% \\
\text { availabl } \\
\text { e SMR }\end{array}$ & $\begin{array}{c}50 \% \\
\text { availabl } \\
\text { e SMR }\end{array}$ & $\begin{array}{c}25 \% \\
\text { availabl } \\
\text { e SMR }\end{array}$ & $\begin{array}{c}\text { Mea } \\
\mathbf{n}\end{array}$ \\
\hline IR-42 & 223.43 & $\begin{array}{c}178.98 \\
(19.9)\end{array}$ & $\begin{array}{l}157.96 \\
(29.3)\end{array}$ & $\begin{array}{c}186 . \\
79\end{array}$ & 69.63 & $\begin{array}{l}79.16 \\
(12.0)\end{array}$ & $\begin{array}{l}87.96 \\
(20.8)\end{array}$ & 78.92 \\
\hline $\begin{array}{l}\text { NDR- } \\
8002\end{array}$ & 237.63 & $\begin{array}{c}214.57 \\
(9.7)\end{array}$ & $\begin{array}{c}201.80 \\
(15.1)\end{array}$ & $\begin{array}{c}218 . \\
00\end{array}$ & 74.53 & $\begin{array}{l}99.14 \\
(24.8)\end{array}$ & $\begin{array}{l}117.45 \\
(36.5)\end{array}$ & 97.04 \\
\hline BPT-5204 & 225.57 & $\begin{array}{c}194.00 \\
(14.00)\end{array}$ & $\begin{array}{l}173.41 \\
(23.12)\end{array}$ & $\begin{array}{c}197 . \\
66\end{array}$ & 71.90 & $\begin{array}{l}86.45 \\
(16.8)\end{array}$ & $\begin{array}{l}93.13 \\
(22.8)\end{array}$ & 83.83 \\
\hline TCA-48 & 229.47 & $\begin{array}{c}201.10 \\
(12.4)\end{array}$ & $\begin{array}{c}185.18 \\
(19.3)\end{array}$ & $\begin{array}{c}205 . \\
25\end{array}$ & 66.98 & $\begin{array}{l}96.34 \\
(30.5)\end{array}$ & $\begin{array}{l}111.78 \\
(40.0)\end{array}$ & 91.70 \\
\hline Mean & 229.23 & $\begin{array}{c}197.16 \\
(14.0)\end{array}$ & $\begin{array}{l}179.59 \\
(21.6)\end{array}$ & & 70.76 & $\begin{array}{l}90.27 \\
(21.6)\end{array}$ & $\begin{array}{l}102.58 \\
(31.0)\end{array}$ & \\
\hline S.Em $( \pm)$ & $V=4.73$ & \multicolumn{2}{|c|}{$\begin{array}{l}\mathrm{D}=4.09 \\
8.19\end{array}$} & $\mathrm{D}=$ & $V=2.07$ & \multicolumn{2}{|c|}{$\begin{array}{c}D=1.79 \\
3.58\end{array}$} & $\mathbf{D}=$ \\
\hline $\begin{array}{c}\text { LSD at } \\
5 \%\end{array}$ & $V=13.67$ & \multicolumn{2}{|c|}{$\begin{array}{l}D=11.83 \\
=\mathrm{NS}\end{array}$} & $V \times D$ & $V=5.97$ & \multicolumn{2}{|c|}{$\begin{array}{l}D=5.17 \\
10.34\end{array}$} & $\mathbf{D}=$ \\
\hline
\end{tabular}

(SMR: Soil moisture regime; NS: Not significant)

(Values in parenthesis indicate percent decrease due to $50 \%$ and $25 \%$ available SMR calculated over $100 \%$ available SMR)

The percent increase in the proline content at $50 \%$ and $25 \%$ available SMR with respect to saturated condition varied from $12 \%$ (IR-42) to $30.5 \%$ (TCA-48) and $20.8 \%$ (IR-42) to $40 \%$ (TCA-48), respectively. At recovery, all 4 varieties showed higher proline at $50 \%$ and $25 \%$ available SMR with respect to saturated condition, however values were less than that found at end of the drought. The mean effect of stress exhibited $21.6 \%$ and $31.0 \%$ increase in proline content at $50 \%$ and $25 \%$ available SMR, respectively over saturated condition.

The increase in free proline content under water deficit condition could occur due to de novo synthesis of proline or breakdown of proline rich proteins or shift in metabolism. According to Dubey (1997), increase in proline level helps the cell in osmoprotection as well as in regulating their redox potential, scavenging hydroxyl radicals and protection against denaturation of various macro molecules. Higher proline accumulation under drought has been also observed by a number of researchers (Blum, 1998; Mostajenan and Rahimi-Eichi, 2009). High proline content of NDR-8002 and TCA-48 might have contributed to increasing water absorption capacity of plant through osmotic adjustment and provided a readily available pool of nitrogen at recovery. Hence, proline is considered as a measure of drought resistance in various crops. High proline accumulation under stress might be a tolerant trait for drought.

The grain and biochemical processes of rice were adversely affected due to moisture deficit stress at flowering stage. Rice varieties NDR8002 and TCA-48 have the potential to produce better yield under moisture deficit stress . Initial high carbohydrate coupled with 
less reduction under stress seems to be useful adaptive trait for flowering stage drought tolerance. High proline accumulation under moisture deficit stress can also be taken as a measure of flowering stage drought tolerance. High apparent translocation rate value is an indicator of high stem reserve mobilization to sink during moisture. This parameter can be used to screen large number of genotypes for flowering stage drought tolerance. Maintenance of good relative leaf water content during moisture deficit stress can be considered adaptive trait for drought tolerance. Rice varieties NDR-8002 and TCA-48 have adaptive features for flowering stage drought tolerance and may be used as tolerant lines under breeding programme. Further studies are required to validate present results with larger population and search other tolerant traits.

\section{Acknowledgements}

The technical and informative supports of the Department of Crop Physiology, Narendra Deva University of Agriculture and Technology, Kumarganj, Faizabad, Uttar Pradesh, India for conducting such physiochemical research on rice without any external fund-assistance are highly acknowledged.

\section{Conflict of interest}

There is no conflict of interest among the authors.

\section{Ethical approval}

This article does not contain any studies with human participants or animals performed by any of the authors.

\section{ORCID}

https://orcid.org/0000-0003-2093-7397

\section{References}

Arnon, D. I. (1949). Copper enzyme is isolated chloroplast, polyphenyl oxidase in Beta vulgaria. Plant Physiology, 24: 1-15.

Arti (2006). Response of flowering stage water deficit on growth, apparent translocation rate, yield and yield components of upland rice. Thesis submitted in N. D. U. A. \& T., Kumarganj, Faizabad : 67-69.

Austin, R. B.; Margin, R. B.; Ford, M. A., and Blackwell, R. D. (1980). Contribution to grain yield from pre-anthesis assimilation in tall and dwarf genotypes in two contrasting seasons. Annals of Botany (London), 45: 30919.

Bates, L. S., Waldren, R. P., and Teare, T. D. (1973). Rapid determination of freeproline for water stress studies. Plant and Soil, 39: 205-8.

Blum, A. (1998). Improving wheat grain filling under stress by stem reserve mobilization. Eyphytica, 100: 77-83.

Bouman, B. A. M., Peng, S., Castaoeda, A. R., and Visperas, R.M. (2005). Yield and water use of irrigated tropical aerobic rice systems. Agricultural Water Management, 74(2): 87-105.

Chaturvedi, G. S., and Ingram, K. T. (1989). Assimilate accumulation and remobilization for flowering stage drought tolerance in rice Saturday seminar published (Post Doctoral Work). IRRI, Philippines, pp. 171.

Chaturvedi, G. S., and Ingram, K. T. (1991). Effect of atrazine and moisture stress on translocation of assimilates. Plant Physiology and Biochemistry, 18(1): 40-42.

Chaturvedi, G. S., Singh, B. B., Singh, A. K., Singh, M. K., and Singh, V. N. 2004. Carbohydrate accumulation and remobilization of upland and lowland 
rice in response to water deficit in various developmental stages. Resilient crops for water limited environments: Proceedings of the workshop held at Cuernavaca Mexico. 24-28 May 2004. Pp-148-149.

Cooper, M. (1999). Concepts and strategies for plant adaptation research in rainfed lowland rice. Field Crops Research, 64(1-2): 13-34.

Dubey, R. S. (1997). In strategies for improving salt tolerance in higher plants. Science Publishers Inc., USA pp. 129-158.

HongBo, S., Zong-suo, L., and Ming-An, S. (2005). LEA protein in higher plants: Structure, function and gene expression and regulation. Colloids Surf B Biointerfaces, 45:131-135.

Kar, M., Patro, B. B., Sahoo, C. R., and Hota, B. (2005). Traits related to drought resistance in cotton hybrids. Indian Journal Plant Physiology, 10: 377380.

Mostajenan, A., and Rahimi-Eichi, V. (2009). Effect of drought stress on growth and yield of rice (Oryza sativa L.) cultivars and accumulation of proline and soluble sugars in sheath and blades of their different ages leaves. AmericanEurasian Journal of Agricultural and Environment Science, 5(2): 264-272.

Pandey, U. N., and Chaturvedi, G. S. (1993). Evaluation of Roy, S.K.B. (1987). Variability in yield and yield components of normal and late sown rice in West Bengal. International Rice Research, Newsletter, 12(3): 18-19.

Panse, V. G., and Sukhatme, P. V. (1978). Statistical method for agricultural workers. ICAR Publication, New Delhi.

Ram, P., Ram, P. C., and Singh, B. B. (1988). Response of rice genotypes to water stress imposed at the tillering and boot stages of growth. Indian Journal of
Plant Physiology, 31: 308-11.

Reyniers, F. N., Troung-Binn, jackinot, L., and Nicon, R. (1982). Breeding drought resistance in dry land rice. In : Drought resistance in crop with emphasis on rice. International Rice Research Institute, Los Banos, Philippines, pp. 273-292.

Samier, K. H. S., and Mafrina, K. G. (1982). The ultra structure of chloroplast of cotton under water deficit. FiziologiyaBiokhimiyaKulturnykh. Restenil, 14(4), 346-349.

Sarvestani Z. T., HemmatollahPirdashti, Seyed Ali Mohammad Modarres Sanavy, and HamidrezaBalouchi (2008). Study of water stress effects in different growth stages on yield and yield components of different rice (Oryza sativa L.) cultivars. Pakistan Journal of Biological Science, 11(10): 1303-1309.

Sheshshayee, M. S., Bindumadhava, H., Shankar, A. G., Prasad, T. G., and Udayakumar, M. (2003). Breeding strategies to exploit water use efficiency for crop improvement. Indian Journal of Plant Physiology, 30: 253-268.

Sikuku, P. A., Netondo, G. W., Onyango, J. C., and Musyimi, D. M. (2010). Chlorophyll fluorescence, protein and chlorophyll content of three nerica rainfed rice varieties under varying irrigation regimes. ARPN Journal of Agricultural and Biological Science, 5(2): 1990-6145.

Tao, H., Brueck, H., Dittert, K., Kreye, C., Lin, S., and Sattelmacher, B. (2006). Growth and yield formation of rice (Oryza sativa L.) in water-saving ground cover rice production system (GCRPS), Field Crops Research, 95(1): 1-12.

Turner, N. C., and Beg, J. E. (1981). Plant water relation and adaptation to stress. 
Plant and Soil, 58: 97-31.

Weng, J. H., Agata, W., and Takeda, T. (1986). Studies on dry matter and grain production of rice plants. IV. Varietal differences of total carbohydrate content of heading stage. Japanese Journal of Crop Science, 55(2): 201207.

Yang, J. C., Liu, K, Zhang, S. F., Wang, Zh.

X. M., Wang, Q., and Liu, L. J. (2008).
Hormones in rice spikelets in responses to water stress during meiosis Acta AgronomicaSinica, 34(1): 111-118.

Yemm, E. W., and Willis, A. J. (1954). The estimation of carbohydrate in plant extracts by anthrone. Journal of Biochemistry, 57: 508-514.

\section{How to cite this article:}

Prabhasmita Shatpathy, Arti, Surendra Pratap Singh, Sanat Kumar Dwibedi and Abhiram Dash 2019. Assessment of Physiological Traits for Adaptation to Flowering Stage Water Deficit in Rainfed Lowland Rice (Oryza sativa L.). Int.J.Curr.Microbiol.App.Sci. 8(10): 245-255. doi: https://doi.org/10.20546/ijcmas.2019.810.025 